\title{
O papel do silício nas plantas
}

\author{
The role of silicon in plants \\ El papel del silicio en las plantas
}

Leônidas Canuto dos Santos ORCID: https://orcid.org/0000-0002-0385-4736 Universidade Federal de Lavras, Brasil

E-mail: leonidas.santos1@estudante.ufla.br

Guilherme Augusto Mendes da Silva ORCID: https://orcid.org/0000-0001-7282-2511 Universidade Federal de Lavras, Brasil

E-mail: guilherme.silva15@estudante.ufla.br

Mikaela de Oliveira Abranches ORCID: https://orcid.org/0000-0002-8280-8593 Universidade Federal de Viçosa, Brasil

E-mail: mikaela.abranches@ufv.br

Josinaldo Lopes Araújo Rocha ORCID: https://orcid.org/0000-0003-4669-6114 Universidade Federal de Campina Grande, Brasil E-mail: jhosinal_araujo@yahoo.com.br Smyth Trotsk de Araújo Silva ORCID: https://orcid.org/0000-0002-9452-9655 Universidade Federal de Campina Grande, Brasil E-mail: smythtrotsk18@gmail.com

Michel Douglas Santos Ribeiro

ORCID: https://orcid.org/0000-0001-5932-7460 Universidade Federal do Ceará, Brasil E-mail: mycheldouglass@gmail.com

Valeria Ribeiro Gomes

ORCID: https://orcid.org/0000-0003-4231-8861 Universidade Federal de Campina Grande, Brasil E-mail: valeriaribeiro1996@ hotmail.com

Pedro Jorge da Silva Severo

ORCID: https://orcid.org/0000-0001-6751-8902

Universidade Federal de Campina Grande, Brasil

E-mail: pjorgesevero33@gmail.com

Cledinildo Lopes Brilhante

ORCID: https://orcid.org/0000-0003-2874-6915 Universidade Federal de Campina Grande, Brasil E-mail: cledinildo.lopes@estudante.ufcg.edu.br

Flaubert Queiroga de Sousa

ORCID: https://orcid.org/0000-0001-5353-8726

Universidade Federal de Campina Grande, Brasil E-mail: fqagronomo@gmail.com

\begin{abstract}
Resumo
O silício ( $\mathrm{Si}$ ) é o segundo elemento mais abundante na crosta terrestre. Este elemento é encontrado na forma de óxidos $\left(\mathrm{SiO}_{2}\right)$, constituindo os minerais silicatados formadores de rochas e sedimentos como areia, silte e argila. Entretanto, não é considerado essencial para o pleno desenvolvimento das plantas, em decorrência de atuar apenas de forma indireta no desenvolvimento destas, sendo, portanto, considerado elemento benéfico. O Si pode atuar aumentando a capacidade fotossintética, reduzindo a taxa transpiratória, proporcionando maior resistência à estresses bióticos e abióticos. A presença de Si nos solos tropicais é baixa, decorrente do intenso processo de intemperismo que ocorrem nestes. Dessa forma, no Brasil, muitos são os pesquisadores que se dedicam ao estudo deste elemento, visando identificar os benefícios proporcionados e entender as condições de ocorrência. Assim, a presente revisão de literatura tem como objetivo compilar informações acerca do $\mathrm{Si}$, e o seu papel nas plantas, como atenuante de estresses bióticos e abióticos.
\end{abstract}

Palavras-chave: Elemento benéfico; Estresse ambiental; Silicato; Resistência vegetal.

\section{Abstract}

Silicon ( $\mathrm{Si}$ ) is the second most abundant element in the earth's crust. This element is found in the form of oxides ( $\mathrm{SiO} 2)$, constituting the silicate minerals that form rocks and sediments such as sand, silt and clay. However, it is not 
considered essential for the full development of plants, due to acting only indirectly in the development of these, being therefore considered a beneficial element. Si can act by increasing the photosynthetic capacity, reducing the transpiratory rate, providing greater resistance to biotic and abiotic stresses. The presence of $\mathrm{Si}$ in tropical soils is low, due to the intense weathering process that occurs in these. Thus, in Brazil, many researchers are dedicated to the study of this element, aiming to identify the benefits provided and understand the conditions of occurrence. Thus, the present literature review aims to compile information about $\mathrm{Si}$, and its role in plants, as a mitigation of biotic and abiotic stresses.

Keywords: Beneficial elemento; Environmental stress, Silicate; Plant resistance.

\section{Resumen}

El silicio ( $\mathrm{Si}$ ) es el segundo elemento más abundante en la corteza terrestre. Este elemento se encuentra en forma de óxidos ( $\mathrm{SiO} 2)$, constituyendo los minerales silicatos que forman rocas y sedimentos como arena, limo y arcilla. Sin embargo, no se considera imprescindible para el pleno desarrollo de las plantas, por actuar solo de forma indirecta en el desarrollo de estas, por lo que se considera un elemento beneficioso. El Si puede actuar aumentando la capacidad fotosintética, reduciendo la tasa de transpiración, proporcionando mayor resistencia a los estreses bióticos y abióticos. La presencia de $\mathrm{Si}$ en suelos tropicales es baja, debido al intenso proceso de meteorización que se produce en estos. Así, en Brasil, muchos investigadores se dedican al estudio de este elemento, con el objetivo de identificar los beneficios brindados y comprender las condiciones de ocurrencia. Por lo tanto, la presente revisión de la literatura tiene como objetivo recopilar información sobre el Si, y su papel en las plantas, como una mitigación de los estreses bióticos y abióticos.

Palabras clave: Elemento beneficioso; Estrés ambiental; Silicato; Resistencia de las plantas.

\section{Introdução}

Para que as plantas se desenvolvam de maneira satisfatória, diversos fatores de produção estão envolvidos, dentre estes se destaca o fornecimento adequado dos nutrientes. Assim, são reconhecidos 17 elementos essenciais para o crescimento e desenvolvimento das plantas, sendo estes: carbono $(\mathrm{C})$, hidrogênio $(\mathrm{H})$, oxigênio $(\mathrm{O})$, nitrogênio $(\mathrm{N})$, fósforo $(\mathrm{P})$, potássio $(\mathrm{K})$, cálcio $(\mathrm{Ca})$, magnésio $(\mathrm{Mg})$, enxofre $(\mathrm{S})$, boro $(\mathrm{B})$, cloro $(\mathrm{Cl})$, cobre $(\mathrm{Cu})$, ferro $(\mathrm{Fe})$, manganês $(\mathrm{Mn})$, molibdênio $(\mathrm{Mo})$, níquel (Ni) e zinco (Zn) (Dechen \& Nachtigall, 2006, p. 92).

No entanto, alguns elementos não são classificados como essenciais, por não atenderem aos critérios de essencialidade, mas atuam melhorando certas respostas das plantas, como por exemplo, o crescimento e desenvolvimento, melhoria do desempenho frente aos estresses bióticos e abióticos e auxílio no uso de outros nutrientes, sendo estes denominados elementos benéficos (Temiz, 2017). Estes são denominados elementos benéficos e diversos estudos são realizados para conhecimento da razão de não essencialidade. Pode-se destacar dentre estes o sódio (Na), cobalto (Co), silício (Si) (Korndörfer \& Souza, 2018, p. 563) e o selênio (Se) (Dechen \& Nachtigall, 2006, p. 126).

Em culturas acumuladoras, como é o caso de algumas espécies da família Chenopodiaceae, tendo destaque a beterraba açucareira e de mesa, o Na pode substituir parcialmente o K (Baliza et al., 2010). A partir dessa substituição o Na pode atuar no controle osmótico, na abertura e fechamento dos estômatos, na fotossíntese e também na ativação enzimática, entretanto as plantas completam seu ciclo de vida na ausência do elemento, o que o torna benéfico, porém não essencial (Malavolta, 2006).

O Si é considerado elemento benéfico para diversas culturas de interesse econômico, como, por exemplo, arroz, batata e cana-de-açúcar (Camargo et al., 2007c; Pulz et al., 2008). A utilização do elemento no país em pesquisas e em cultivos comerciais, foi potencializada após a inclusão deste como micronutriente na legislação de fertilizantes pelo Ministério da Agricultura (Brasil, 2004). O nutriente ocupa 27,7\% da crosta terrestre, sendo o segundo elemento mais abundante, encontrado na forma de óxidos $\left(\mathrm{SiO}_{2}\right)$ na natureza, o qual faz parte de rochas, areia e argila (Dechen \& Nachtigall, 2006, p. 127). A origem do Si é dependente do grau de intemperismo do solo, assim sua presença é maior em solos jovens, a exemplo dos cambissolos (Menegale; Castro \& Mancuso, 2015).

Esse elemento é considerado benéfico por estar relacionado com uma série de efeitos indiretos, como o aumento na capacidade fotossintética, aumento da resistência ao acamamento, redução da taxa transpiratória, estímulo da resistência das 
plantas a pragas e doenças, redução do efeito tóxico do $\mathrm{Mn}, \mathrm{Fe}, \mathrm{Al}$ e Na, além do aumento na absorção de outros elementos, tais como o fósforo (Lana et al., 2003).

Segundo Epstein e Bloom (2004), o Si pode ser considerado elemento "semi essencial" por cumprir o segundo critério de essencialidade, onde as plantas apresentam anormalidades em seu crescimento, desenvolvimento ou reprodução quando comparadas com plantas não privadas do elemento, permitindo considerá-lo como de grande importância para o desenvolvimento de diversas culturas. Assim, um exemplo seria o caso das algas diatomáceas e da cavalinha, planta vascular, as quais não completam seu ciclo na ausência do mesmo (Camargo, 2016a).

As formas de fornecimento de Si para as culturas são através da utilização de escórias de siderurgia, silicatos de Ca, Mg e K (Freitas et al., 2011). Além de fornecer Si para as culturas esses materiais apresentam o potencial de serem utilizados na correção do solo, em decorrência da formação de ácido monossilícico $\left(\mathrm{H}_{4} \mathrm{SiO}_{4}\right)$ resultando em aumento de pH (Nolla, 2013).

Diversas espécies importantes na alimentação humana, incluindo gramíneas (arroz, cana-de-açúcar, aveia, trigo, milho) e não gramíneas (feijão, alface, repolho) apresentam capacidade de acumular silício em seus tecidos, proporcionando maior crescimento e produção (Lana et al., 2003). Assim, a presente revisão de literatura tem como objetivo realizar um estudo bibliográfico, em bases científicas nacionais e internacionais, a respeito do elemento benéfico silício, elucidando sua interação no sistema solo-planta, e seus efeitos frente a ocorrência de estresses em diferentes culturas.

\section{Metodologia}

A seguinte revisão bibliográfica constitui-se da busca de artigos científicos em periódicos com renome, sendo considerados aqueles importantes para o estado da arte relacionado ao estudo do silício. A ferramenta metodológica utilizada no presente estudo, é constituída de uma pesquisa qualitativa baseada em uma revisão de literatura (Pereira et al., 2018). As bases utilizadas para busca foram: Scielo, Web of Science e Science Direct.

\section{Desenvolvimento}

\section{Silício e sua relação com o solo}

O Si é o segundo elemento mais abundante da crosta terrestre, presente em $27,7 \%$ desta, principalmente na forma de óxidos $\left(\mathrm{SiO}_{2}\right)$ constituindo parte das rochas, areia e argila (Dechen \& Nachtigall, 2006, p. 127). É considerado um dos principais formadores dos argilo-minerais no processo de gênese do solo (Menegale; Castro \& Mancuso, 2015). Porém, o teor de Si solúvel e disponível para as plantas pode ser baixo em alguns solos em decorrência principalmente do teor de argila, mineralogia e textura do solo (Camargo, 2016a). Dessa forma, espera-se que solos com maior teor de óxidos de Fe e Al, bem como solos arenosos ou de textura média apresentem menor teor de Si solúvel. Em contrapartida, alguns solos com baixos teores de argila como, por exemplo, argissolos de textura média, podem apresentar teor de Si suficiente para a nutrição das plantas, não sendo responsivos à adubação silicatada (Camargo, 2016a).

As reaçães de dissociação, polimerização e precipitação que ocorrem com o $\mathrm{Si}$ no solo, estão intimamente relacionadas à sua concentração na solução, ao pH do solo e a presença de óxidos de Fe e Al (Korndörfer \& Souza, 2018, p. 565). Segundo Castro (2013) quanto mais elevado o pH do solo, até certo ponto, maior será a disponibilidade de Si no solo e sua absorção pelas plantas. O Si está presente no solo nas seguintes formas: prontamente disponível na forma de ácido monossilícico, Si estrutural presente nos minerais silicatados (Korndörfer \& Souza, 2018, p. 564) e Si adsorvido ou precipitado aos coloides do solo, podendo estes serem de origem orgânica ou mineral (Menegale; Castro \& Mancuso, 2015).

Em média, os solos brasileiros apresentam de 5 a $40 \%$ de Si em sua constituição. A presença de óxido de silício, nos argilominerais, faz com que o mesmo seja o elemento mais abundante no solo, entretanto em decorrência do intenso processo 
de intemperismo presente nos solos tropicais, este se encontra, principalmente, na forma de quartzo e opala ( $\mathrm{SiO} 2 . \mathrm{nH} 2 \mathrm{O}$ ) (Menegale; Castro \& Mancuso, 2015). Este intenso processo de intemperismo, faz com que os minerais primários que contêm Si em sua composição sejam praticamente inexistentes nestas condições (Pereira; Vitti \& Korndörfer, 2003).

De acordo com a série liotrópica, que determina a sequência de preferência em retenção de cátions pelo solo, e consequentemente a susceptibilidade de lixiviação dos elementos, tem-se que o íon silicato apresenta menor poder de agregação, ou seja, grande mobilidade no perfil, facilitando dessa forma a lixiviação, o que resulta em baixos teores nos solos tropicais (Menegale; Castro \& Mancuso, 2015).

A forma prontamente disponível de Si no solo, ácido monossilícico, é resultado principalmente da decomposição de resíduos vegetais, sendo que a ciclagem do $\mathrm{Si}$ nos restos culturais de solos intemperizados pode ser considerada a principal fonte de Si para as plantas (Korndörfer \& Souza, 2018, p. 565). As principais perdas nos solos se dão pela polimerização do ácido silícico, lixiviação e a adsorção promovida pelos óxidos e hidróxidos de Fe e Al (Korndörfer \& Souza, 2018, p. 565).

Nos solos ocorre interação entre o Si e o fósforo devido principalmente a competição pelos mesmos sítios de adsorção (Camargo et al., 2005b). Segundo Epstein e Bloom (2005), o silício desloca o P do coloide, aumentando a concentração deste na solução do solo. Assim, ocorre menor fixação de fósforo nos óxidos de $\mathrm{Fe}$ e Al, devido ao processo de competição, além do aumento de pH promovido pela adubação silicatada (Malavolta, 2006).

Diversos materiais podem ser utilizados como fonte de Si para as plantas, dentre estes se destaca aqueles aplicados aos solos em pó ou granulado, na forma de silicatos de $\mathrm{Ca}$ e de $\mathrm{Mg}$, ou ainda na forma líquida, utilizados na aplicação foliar, como o silicato de K (Korndörfer \& Souza, 2018, p. 566). Normalmente estes materiais são sub produtos de escórias básicas de siderurgia, tendo o potencial de serem utilizadas como corretivos do solo e também como fontes de Si e outros nutrientes, como por exemplo, P, S, Fe, Zn, Cu, B, Mo, Co e outros (Pereira; Vitti \& Korndörfer, 2003).

Dessa forma, em estudo realizado por Pulz et al. (2008), avaliou-se a nutrição e a produtividade da cultura da batata, submetida a diferentes formas de correção do solo, através da utilização de calcário dolomítico, silicato de cálcio e de magnésio. A aplicação dos corretivos foi calculada para elevar a saturação de bases de um latossolo vermelho a $60 \%$. A partir da avaliação dos resultados foi verificado que a aplicação de silicato de Ca e $\mathrm{Mg}$ proporcionou maior disponibilidade de $\mathrm{P}$ e $\mathrm{Si}$ no solo e maior absorção desses elementos pela cultura. Essa avaliação foi realizada a partir da análise foliar, onde estatisticamente o teor de $\mathrm{P}$ do tratamento com silicatos diferiu do tratamento com calcário.

Em trabalho realizado por Melo, Monteiro e Manfredini (2007), foi proposto avaliar os atributos produtivos e fisiológicos durante o estabelecimento do capim Marandu (Braquiaria brizantha), além de avaliar a disponibilidade de fósforo, por meio de adubações silicatadas e fosfatas. O experimento foi realizado sob latossolo vermelho-amarelo distrófico, utilizando combinações de doses de fósforo e silício, sendo a fonte deste a wollastonita. A partir dos resultados foi possível observar interação positiva entre as doses de fósforo e Si utilizadas, para o número de perfilho e folhas verdes expandidas, área foliar total, produção de massa seca das lâminas foliares e a produção de massa seca da parte área. O tratamento que resultou na máxima resposta das variáveis estudadas foi aquele onde houve combinação de doses medianas de fósforo (170 e $\left.250 \mathrm{mg} \mathrm{dm}^{-3}\right)$ com altas doses de silício ( 375 a $450 \mathrm{mg} \mathrm{dm}^{-3}$ ).

Em trabalho realizado por Tokura et al. (2007), avaliou-se o efeito de diferentes doses de Si e P na produção de matéria seca e o acúmulo desses nutrientes nas plantas de arroz. O experimento foi realizado em dois tipos de solo (Neossolo Quartazarênico Órtico - Rqo e Latossolo Vermelho Distroférrico - LVdf), sendo que os tratamentos foram constituídos de quatro doses de $\mathrm{P}\left(0,80,240\right.$ e 410; 0, 110, 330 e $560 \mathrm{mg} \mathrm{dm}^{-3}$, respectivamente, para RQo e LVdf) e três doses de $\mathrm{Si}(0,240$ e 410; 0, 330 e $560 \mathrm{mg} \mathrm{dm}^{-3}$, respectivamente, para RQo e LVdf)). Contudo, a aplicação de Si não promoveu acúmulo de fósforo na parte aérea das plantas, tendo ocorrido apenas acúmulo deste na área foliar destas, além de não ter havido influência na produção de massa seca da parte aérea e de grãos. 
De maneira semelhante, Alovisi et al. (2014) avaliaram a interação de P e Si na produção do feijoeiro. A experimentação consistiu em incubar de forma sequencial dois tipos de solo, Neossolo Quartzarênico - RQo e Latossolo Vermelho - LVdf, de três maneiras: a primeira com calcário, para elevar a saturação de bases a 50\%, a segunda com ácido silícico, com três doses $\left(0,240\right.$ e 410; 0, 330 e $560 \mathrm{mg} \mathrm{dm}^{-3}$, respectivamente, para o RQo e LVdf), e a terceira com fertilização básica, incluindo fósforo, com quatro doses $\left(0,80,240\right.$ e 410; 0, 110, 330 e $560 \mathrm{mg} \mathrm{dm}^{-3}$, respectivamente, para o RQo e LVdf). Ao fim da experimentação foi possível observar que a aplicação de Si não promoveu incrementos na produção da massa seca da parte aérea, tão menos na produção da massa seca dos grãos, além de não propiciar acúmulo de $\mathrm{P}$ na parte aérea das plantas de feijoeiro.

A presença de Si no solo pode promover precipitação do Al, resultado do aumento do $\mathrm{pH}$ (Malavolta, 2006). Segundo Epstein e Bloom (2004), os mecanismos de redução da toxicidade do Al ainda não são totalmente claros, porém acredita-se que possam ocorrer várias co-precipitações dos metais com o $\mathrm{Si}$, o que protege as plantas da toxicidade. Já segundo Freitas, Fernandes e Maia (2012), o acúmulo de Si e Al nas plantas são mutuamente excludentes, ou seja, quando um ocorre o outro deixa de ser acumulado, tal fato pode estar relacionado a uma maior tolerância das plantas, decorrente da maior absorção e acúmulo de Si nos tecidos.

Assim, com o objetivo de verificar a interação entre $\mathrm{Al}$ e Si, Giongo e Bohen (2011) realizaram experimento utilizando dois genótipos de milho, sendo um tolerante e outro sensível a toxidez de alumínio, expostos a presença e ausência de alumínio e silício. Ao fim do experimento verificou-se que o silício reduziu o efeito tóxico do alumínio no crescimento radicular dos genótipos de milho independentemente da sensibilidade ao elemento tóxico. Uma das explicações para tal resultado é a presença do Si ter proporcionado aumento do transporte de Ca para a parte aérea das plantas. A avaliação do extrato aquoso das plantas permitiu verificar as alterações proporcionadas pela interação do silício com o alumínio.

No estudo realizado por Freitas, Fernandes e Maia (2015), foi proposto avaliar os efeitos da aplicação de Si nos teores de macro e micronutrientes, alumínio e silício na parte aérea de plantas de arroz de terras altas, sob estresse por alumínio. O experimento consistiu de duas cultivares, uma tolerante ao $\mathrm{Al}$ e uma não tolerante, submetidas a cinco doses de $\mathrm{Si}(0,30,60$, 90 e $120 \mathrm{mg} \mathrm{dm}^{-3}$ ). A fonte de Si utilizada foi silicato de K, que foi dissolvido em água e aplicado sobre a superfície do solo. O silicato de $\mathrm{K}$ aplicado proporcionou aumento de $\mathrm{Si}$ e redução do teor de alumínio na parte aérea de ambas as cultivares, caracterizando assim a interação de Si e Al na planta. Entretanto, não houve incremento na absorção de macro e micronutrientes. A interação Si e Al no solo não foi verificada, pois não houve alteração na disponibilidade de nutrientes, bem como no teor de $\mathrm{Al}$ e no valor de $\mathrm{pH}$.

Os silicatos mais utilizados na agricultura, como corretivos, são aqueles que contém $\mathrm{Ca}$ e $\mathrm{Mg}$ em sua composição (Malavolta, 2006). No Brasil, o material mais utilizado na correção dos solos é o calcário, o qual apresenta boa eficiência na elevação da fertilidade (Menegale; Castro \& Mancuso, 2015). Entretanto, exige água para sua reação, devendo ser incorporado para uma maior eficácia na correção, além disso sua ação se concentra principalmente na camada de 0 a 20 centímetros de profundidade do solo (Alcarde \& Rodella, 2003). Assim, em sistemas de plantio direto a correção do solo se torna um desafio, pela não ocorrência do revolvimento. Dessa forma, escórias de siderurgia, como silicato de $\mathrm{Ca}$ e $\mathrm{Mg}$, podem ser utilizadas como corretivo da acidez do solo e fonte de silício (Reis et al., 2013), pois estes materiais apresentam solubilidade de até 6,78 vezes maior que o carbonato de cálcio (Alcarde \& Rodella, 2003), ou seja, apresenta maior potencial de ser utilizado para a correção do solo em profundidade.

Assim, em experimento realizado por Ramos et al. (2006), com o objetivo de comparar os efeitos do calcário, gesso e silicatos quanto a sua capacidade em fornecer $\mathrm{Ca}, \mathrm{Mg}, \mathrm{Si}$ e correção do solo em profundidade, foi realizado experimento em um Neossolo Quartzarênico Órtico Típico. Os tratamentos consistiram de silicato de Ca (wollastonita), silicato de Ca e Mg, termofosfato, calcário calcítico e gesso agrícola. $\mathrm{O}$ solo foi incubado por 40 dias, sendo realizado posteriormente a avaliação 
dos resultados. Como era esperado o gesso elevou os teores de Ca, porém não alterou o pH do solo. A utilização dos silicatos, por sua vez, corrigiu a acidez do solo, além de aumentar o teor de Ca de forma mais eficiente do que o calcário. A utilização do silicato de $\mathrm{Ca}$ e $\mathrm{Mg}$ e de termofosfato aumentou consideravelmente o teor de Mg no solo. Além disso, a utilização das fontes silicatadas aumentou o teor de Si no solo, sendo este carreado para as camadas mais profundas.

No estudo realizado por Barbosa Filho et al. (2001), objetivou-se avaliar a aplicação de silicato de Ca sob o rendimento do arroz de sequeiro, além de avaliar o efeito na correção do solo. O experimento consistiu em aplicar seis diferentes doses de $\mathrm{SiO}_{2},\left(0 ; 125 ; 250 ; 375 ; 500\right.$ e $625 \mathrm{mg} \mathrm{kg}^{-1}$ de solo) na forma de wollastonita. Os resultados mostram aumento na produção dos grãos de forma linear, em decorrência principalmente do fornecimento de Ca e Si no sistema soloplanta. Além disso, houve elevação do pH do solo, bem como dos teores de $\mathrm{Ca}, \mathrm{Mg}$ e Si no solo.

Com o objetivo de verificar a eficiência de utilização do silicato de Ca em campo, Ramos et al. (2013), realizaram experimento utilizando doses crescentes de silicato de $\mathrm{Ca}\left(0,700,1400,2800,5600 \mathrm{~kg} \mathrm{ha}^{-1}\right)$. O intuito foi avaliar os atributos químicos do solo, além da produção de cana-de-açúcar. Ao final da experimentação verificou-se que o silicato elevou o valor de pH, Ca, Mg, Fe, Mn, SB, CTC e V\% e diminuiu os teores de (H+Al), MO, Zn, Cu e Si. A produção da cana-de-açúcar aumentou de forma linear com as doses de silicato de cálcio, portanto o resultado demonstra que a cultura é altamente responsiva a correção do solo com Si.

\section{Silício e sua relação com as plantas}

A absorção de $\mathrm{Si}$ da solução do solo ocorre preferencialmente na forma de ácido monossilícico $\left(\mathrm{H}_{4} \mathrm{SiO}_{4}\right)$, sendo que sua concentração varia de 0,1 a 0,6 mmol L-1 (Epstein, 1999). A entrada de Si nas células das raízes pode ocorrer pela ocupação do simplasto ou apoplasto, através do processo de difusão ativa ou por canais de água (Raven, 2001). A absorção também pode ocorrer por meio de proteínas de membranas específicas para o ácido monossilícico (Korndörfer \& Souza, 2018, p. 566). Assim, o Si é considerado o único elemento que quando absorvido em excesso pelas plantas não acarreta prejuízos no seu desenvolvimento (Camargo, 2016a).

As plantas não acumuladoras de $\mathrm{Si}$ o absorvem mais lentamente que a água, propiciando o aumento de sua concentração no meio, enquanto as plantas acumuladoras absorvem de forma passiva, sendo potencializada pelo fluxo em massa da água (Lana et al., 2003). Após a absorção ocorre o transporte a longa distância pelo xilema, sendo alocado na parede celular na forma de sílica amorfa hidratada ou opala biogênica $\left(\mathrm{SiO}_{2} \mathrm{nH}_{2} \mathrm{O}\right)$, contribuindo com a rigidez e elasticidade dos tecidos (Moreira et al., 2010).

A maior concentração de Si nas plantas se localiza em tecidos de suporte do caule e das folhas, sendo que $99 \%$ do elemento acumulado encontra-se na forma de ácido silícico polimerizado, apresentando reduzida solubilização, consequentemente baixa redistribuição (Menegale; Castro \& Mancuso, 2015). Outro fato relevante é que a acumulação de Si é maior nas regiões onde ocorre perda de água, tanto por evaporação quanto transpiração, sendo as folhas os órgãos mais ativos nesse aspecto (Lana et al., 2003).

De acordo com a capacidade de absorção e acúmulo de Si nos tecidos, as plantas podem ser classificadas em três grupos: plantas acumuladoras (100 a $150 \mathrm{~g} \mathrm{~kg}^{-1} \mathrm{de} \mathrm{Si}$ ), intermediárias (10 a $50 \mathrm{~g} \mathrm{~kg}^{-1} \mathrm{de} \mathrm{Si}$ ) e não-acumuladoras (concentrações abaixo de $5 \mathrm{~g} \mathrm{~kg}^{-1} \mathrm{de} \mathrm{Si}$ ) (Ma et al., 2001). Em gramíneas o teor do elemento no tecido vegetal pode ser de 10 a 20 vezes maior do que nas dicotiledôneas (Van Raij, 2011).

A deposição de silício como sílica hidratada amorfa $\left(\mathrm{SiO}_{2} \cdot \mathrm{nH}_{2} \mathrm{O}\right)$, ocorre em primeiro lugar no retículo endoplasmático, na parede celular e nos espaços intercelulares (Dechen \& Nachtigall, 2006, p. 127). Assim, quando o acúmulo ocorre nas paredes celulares dos órgãos de transpiração, acontece a formação de uma dupla camada de sílica-cutícula e sílicacelulosa (Ma \& Yamaji, 2006). Em decorrência da formação desta camada protetora há redução do processo de transpiração 
pelas plantas (Barbosa Filho et al., 2001). Dessa forma, o desempenho das plantas em condição de veranico será melhor, ou seja, maior resistência frente ao estresse ambiental.

A formação desta camada protetora contribui, ainda, para uma maior resistência mecânica das células, tornando as plantas mais resistentes frente ao ataque de pragas e doenças (Lana et al., 2003). Além disso, ocorre redução no acamamento e melhoria na captação de energia solar (Ribeiro et., 2011). Em estudo realizado por Pulz et al. (2008), após as aplicações de silicato de $\mathrm{Ca}$ e $\mathrm{Mg}$ na cultura da batateira, foi verificado menor acamamento das hastes e também maior altura das plantas, consequentemente houve maior produção de tubérculos comercializáveis.

Em trabalho realizado por Gao et al. (2006) objetivou-se caracterizar o efeito da aplicação de Si, na taxa transpiratória do milho. As plantas foram cultivadas em soluções nutritivas com e sem $\mathrm{Si}$, nas doses de 0 a $2 \mathrm{mmol} \mathrm{L}^{-1}$, além de ter sido administrado dois níveis de estresse hídrico. Após a avalição dos resultados foi possível concluir que a aplicação de Si reduziu consideravelmente a taxa transpiratória, tanto na parte abaxial quanto na adaxial das folhas, porém estes efeitos não foram observados na cutícula. Assim, é possível predizer que a ação do Si está intimamente relacionada a abertura e fechamento dos estômatos das plantas, e não sobre a condutância da cutícula. A partir das avaliações foliares não foi observado alteração na morfologia e densidade dos estômatos, assim tal efeito de redução da transpiração pode estar associado a uma maior deposição de sílica nas paredes das células epidérmicas.

Ademais, a partir da nutrição das plantas com fontes de Si, é possível observar aumento da capacidade fotossintética. Isso pode estar relacionado à presença do elemento, que proporciona um bom desenvolvimento da arquitetura foliar das plantas, permitindo com que as folhas permaneçam mais eretas e livre de possíveis danos, seja por fatores bióticos ou abióticos (Menegale; Castro \& Mancuso, 2015).

Dessa forma, com o objetivo de investigar o efeito do elemento na capacidade fotossintética e no metabolismo antioxidativo do algodoeiro Curvelo et al (2013), avaliaram o efeito da aplicação do elemento, durante o processo infeccioso por Ramularia areola, agente infeccioso da mancha de ramulária. A nutrição das plantas foi realizada através de solução nutritiva, tendo como fonte de $\mathrm{Si}$, o silicato de potássio, sendo fornecido para as plantas como ácido monossilícico. Ao final da experimentação foi possível concluir que a aplicação de Si afetou a fisiologia das plantas durante o processo infeccioso, auxiliando na manutenção da integridade da membrana plasmática, consequentemente, proporcionou melhor capacidade fotossintética, além de ter elevado as concentrações de clorofila a e b. Ocorreu também aumento da ação do sistema antioxidante das plantas tratadas com o $\mathrm{Si}$, principalmente, da dismutase do superóxido, peroxidase do ascorbato e lipoxigenase, reduzindo os efeitos da infecção da doença.

A fim de avaliar a utilização de silicato de sódio ( $\mathrm{Si}=63 \%$ e Na2 O $=18 \%$ ), silicato de potássio ( $\mathrm{Si}=26 \%$ e $\mathrm{K}=$ $13 \%$ ) e rocksil (pó de rocha moída $-\mathrm{Si}=17 \%, \mathrm{Ca}=12 \%$ e $\mathrm{K}=3 \%$ ), Sávio et al (2011) procederam com aplicações foliares na dose correspondente a $40 \mathrm{~g} \mathrm{~L}^{-1}$ de Si em plantas de Braquiaria decumbes cv. Basilisk e Panicum maximum cv. Mombaça, com o objetivo de avaliar as características agronômicas e conteúdos foliares do elemento. Ao final do experimento foi possível concluir que as aplicações de Si promoveram acréscimos na produção de matéria seca, principalmente na cv. Mombaça. Além disso, houve aumento na concentração média do elemento na parte aérea das duas espécies, independente da fonte de Si utilizada.

No trabalho realizado por Pereira et al. (2010) objetivou-se avaliar a resposta da soja a diferentes doses de Si no plantio, por meio da produtividade e características agronômicas. Foram administradas onze doses de Si na experimentação ( 0 , 50, 100, 150, 200, 250, 300, 350, 400, 450 e $500 \mathrm{~kg} \mathrm{ha}^{-1}$ ) que foram aplicados no sulco de plantio. No fim do experimento foi possível avaliar que as doses utilizadas não proporcionaram aumentos significativos na produtividade dos grãos. Aquela que proporcionou a maior produtividade média $\left(3292 \mathrm{~kg} \mathrm{ha}^{-1}\right)$ foi de $350 \mathrm{~kg} \mathrm{ha}^{-1} \mathrm{de} \mathrm{Si}$, porém esta não diferiu estatisticamente da produtividade média da dose $0 \mathrm{~kg} \mathrm{ha}^{-1}$ que foi $2931 \mathrm{~kg} \mathrm{ha}^{-1}$. Entretanto, com o aumento das doses verificou-se aumento 
significativo no número de legumes por planta, maior altura de plantas, bem como maior altura da inserção do primeiro legume.

Já em estudo realizado por Teodoro et al. (2014), foi avaliado o efeito da aplicação foliar de Si, no acúmulo de matéria seca da soja, em resposta ao déficit hídrico sofrido pela cultura ao longo do ciclo. A fonte de Si utilizada foi o silicato de potássio, sendo este aplicado no estádio de V3, V8 e R5 conforme a escala fenológica, sendo a dose ministrada de $500 \mathrm{~mL}$ $\mathrm{ha}^{-1}$. Ao final do experimento foi possível determinar que em condições de déficit hídrico, a aplicação foliar de $\mathrm{Si}$ proporcionou o desenvolvimento normal das plantas, ocorrendo maior acúmulo de massa seca de haste, ramos, folhas e pecíolos, cápsulas de vagens e sementes durante toda a sua fase reprodutiva.

Na pesquisa realizada por Ludwig, Behling e Schmitz (2015), determinou-se os efeitos da aplicação de silicato de potássio, na produção e qualidade dos frutos de tomate colhidos. Os autores concluíram que a aplicação de Si apresentou pouco efeito nos quesitos avaliados. Entretanto, em trabalho realizado por Nunes et al. (2019) também na cultura do tomate, avaliouse os efeitos da aplicação de Si, via foliar, na cultura submetida ao estresse hídrico. Após as avaliações concluiu-se através dos atributos agronômicos que a dosagem de $50 \mathrm{ml} \mathrm{L}^{-1}$ de Si reduziu os efeitos provocados pelo déficit hídrico. Dessa forma, é possível predizer que os efeitos da aplicação de Si estão associados muitas vezes a condições estressantes, nas quais seus efeitos são mais pronunciados.

\section{Silício e sua relação com o estresse abiótico}

\section{Silício e o estresse hídrico}

Notadamente, o silício ( $\mathrm{Si}$ ) é um elemento benéfico que tem ganhado destaque em sua utilização como fertilizante para o enfrentamento do estresse abiótico. Rodrigues et al. (2011) destacam sua utilização como fertilizante para espécies de importância agrícola, não somente no Brasil, mas no Japão, Estados Unidos, Ilhas Maurício, Austrália e África do Sul.

Os benefícios que este elemento tem trazido às plantas na resistência ao estresse abiótico são divididos em dois grupos: físicos e fisiológicos (Cantuário et al., 2014). O acúmulo do Si na parede celular das plantas se relaciona aos benefícios físicos, assim, criando uma barreira contra a perda de água (Tabela 1) e melhorando a arquitetura das plantas (Korndorfer et al., 2002), em função da deposição do elemento na parede celular de folhas, caule e raízes.

Tabela 1. Potencial hídrico e teor de água em plantas de trigo sob déficit hídrico em função da presença e ausência de adubação silicatada.

\begin{tabular}{ccc}
\hline Tratamento & Potencial hídrico (MPa) & Água (\%) \\
\hline Controle & $-1,03 \mathrm{a}$ & $77,54 \mathrm{a}$ \\
Déficit hídrico $-\mathrm{Si}$ & $-1,49 \mathrm{c}$ & $74,79 \mathrm{~b}$ \\
Déficit hídrico $+\mathrm{Si}$ & $-1,27 \mathrm{~b}$ & $77,49 \mathrm{a}$ \\
\hline
\end{tabular}

Fonte: Gong et al. (2005), adaptado.

Do ponto de vista fisiológico os benefícios do Si se relacionam com uma maior atividade fotossintética, supressão de pragas, resistência ao ataque de microrganismos fitopatogênicos, indução de reações metabólicas que formam compostos como fitoalexinas e lignina que beneficiam as plantas na tolerância à seca (Pozza et al., 2004). Além disso, potencializa a atividade de enzimas como quintinases, peroxidadese e polifenoloxidases (Liang; SUN, 2005).

Ademais, é um elemento que atua beneficiando a ação de defesa antioxidativa das plantas, em resposta ao estresse hídrico e aumento de temperatura, pois nestas condições as plantas acumulam peróxido de hidrogênio e prolina, assim o Si atua 
aumentando a resistência estomática e reduzindo o dano oxidativo em moléculas funcionais (Crusciol et al., 2009; Gunes et al., 2007).

Fatima et al. (2020) ao estudarem o acúmulo de fitomassa em pimentão sob estresse hídrico e doses de Si, concluíram que aplicação de $5,19 \mathrm{~kg} \mathrm{ha}^{-1}$ deste elemento tem reflexos positivos no aumento da fitomassa fresca da hortaliça sob condições de regime hídrico deficitário, amenizando os efeitos deletérios do estresse. Ao estudarem a tolerância ao estresse hídrico em plantas de tomateiro, Nunes et al. (2019) obtiveram resultados médios superiores no número de folhas quando utilizaram doses de silicato de potássio de 25 e $50 \mathrm{~mL} \mathrm{~L}^{-1} \mathrm{sob}$ condições de estresse, quando comparados com a testemunha. Segundo Anjum et al. (2011) plantas aceleram a senescência da abscisão foliar quando estão sob baixa disponibilidade hídrica, sendo que a adubação silicatada beneficia as plantas em situação de estresse através do aumento no número de folhas (Adatia \& Besford, 1986).

\section{Silício e o estresse salino}

A salinidade se caracteriza por provocar um dos estresses abióticos mais eminentes em regiões áridas e semiáridas, contribuindo para elevadas perdas em produção nessas regiões, devido a grandes contrastes ambientais (PARIDA; DAS, 2004). Ahmad (1992) conseguiu resultados satisfatórios na produção de trigo sob efeito de doses de Si na redução da toxidez provocada pela salinidade $(\mathrm{Na})$, posteriormente, a aplicação de Si proporcionou resultados semelhantes em culturas distintas, como Prosopis juliflora (Bradbury \& Ahmad, 1990), Anacardium occidentale e Moringa oleífera (Miranda, 2002).

A prolina é o aminoácido que auxilia diretamente na integridade das membranas celulares contra o efeito deletério de espécies reativas de oxigênio e turgescência das células, por atuar no ajustamento osmótico (Taiz \& Zeiger, 2013). Seu acúmulo nas espécies vegetais diminuem os efeitos negativos do estresse abiótico, especialmente, salino e hídrico (Gill \& Tuteja, 2010). Na Figura 1 a seguir, Araújo (2017) estudou cinco genótipos de feijão-caupi, sob duas condições de regime hídrico e três doses de Si. O autor constatou que a dose de $49 \mathrm{mg} \mathrm{L}^{-1}$ de Si proporcionou maior produção de prolina mesmo em condição de déficit hídrico.

Figura 1. Teor de prolina livre (PRL) nos genótipos de feijão-caupi: Paulistinha (G1), BRS Rouxinol (G2), BRS Marataoã (G3), BR 17 Gurgueia (G4) e Costela de Vaca (G5), condicionados a dois regimes hídricos (W-100 e W-50) e três concentrações de Si $\left(0 ; 49\right.$ e $\left.70 \mathrm{mg} \mathrm{L}^{-1}\right)$, no estádio fenológico V9. Letras minúsculas diferenciam os genótipos. Letras maiúsculas diferenciam as duas condições hídricas.

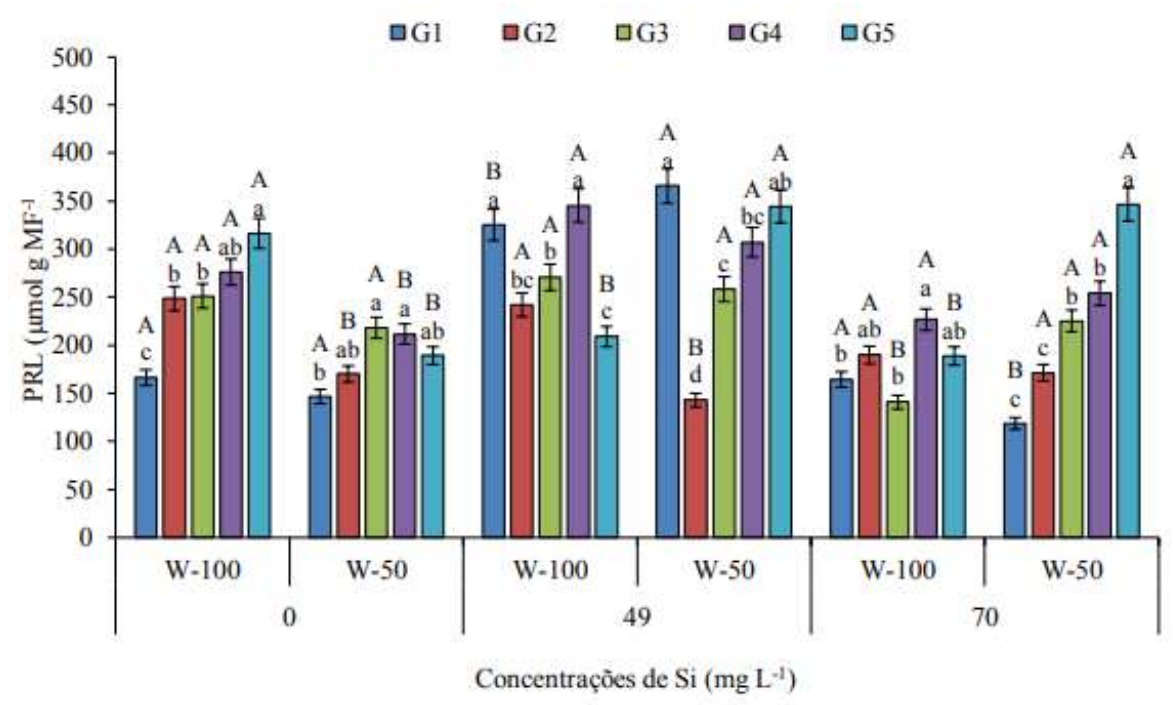

Fonte: Araújo (2017). 
Estudando a ação do Si em condições de salinidade para cultura do pimentão Manivannan et al. (2016), observaram que este elemento provoca efeitos benéficos à cultura, sendo estes resultados atribuídos à capacidade do Si prevenir danos oxidativos através do aumentado das atividades das enzimas antioxidantes, além disso, a adubação silicatada diminuiu o desequilíbrio nutricional em condições de salinidade.

Utilizando Si na redução do estresse salino em plantas de sorgo, Nascimento et al. (2014) concluíram que as cultivares de sorgo BRS 310 e BRS 800, tiveram seu crescimento melhorado e os efeitos deletérios do estresse salino reduzidos sob influência das concentrações de $1 \mathrm{mM}$ e $3 \mathrm{mM}$ de Si. Da mesma forma, Leitzke et al. (2014) testaram a casca de arroz carbonizada como fonte de $\mathrm{Si}$ e concluíram que a utilização de aproximadamente $1000 \mathrm{~kg} \mathrm{ha}^{-1}$ ameniza o efeito negativo do estresse salino em plantas de soja, aumentando a massa seca das plantas, além do número de sementes produzidas.

\section{Silício e o estresse por elementos tóxicos}

O potencial hidrogeniônico do solo $(\mathrm{pH})$ é uma variável que influi diretamente sobre a atividade e disponibilidade de nutrientes. Sabe-se que aproximadamente $68 \%$ dos solos brasileiros são ácidos e afetados pelo alumínio, que pode reduzir em até $40 \%$ a produtividade das culturas (Quaggio, 2000). Assim em pH abaixo de 5,5, ocorre a solubilização do alumínio trivalente $\left(\mathrm{Al}^{3+}\right)$, tornando-o facilmente disponível na solução do solo e podendo ser prontamente absorvido pelo sistema radicular das plantas (Silva et al., 2018).

Alguns estudos demonstram que sob algumas condições o Si diminui o efeito da toxicidade por Al. Freitas et al. (2015), destaca que muitas pesquisas apontam a interação entre Al e Si que ocorre no interior das plantas, por meio do estímulo do sistema antioxidante, ocorrendo a complexação dos íons metálicos, imobilização durante o crescimento da espécie vegetal ou compartimentalização no vacúolo e citoplasma (Neuman \& Nieden, 2001). Outra possibilidade é a ocorrência de formação do complexo entre $\mathrm{Al}$ e Si externamente à planta, amenizando a toxidez por Al (Sousa Junior, 2019).

$\mathrm{Em} \mathrm{pH}$ próximo a neutralidade o Si têm a capacidade de formar com o Al hidroxialuminossilicatos, que reduzem os efeitos deletérios da toxicidade (Hodson \& Sangster, 1999), conforme a equação a seguir:
${ }_{n A 1} \mathbf{3}^{3+}$
$\leftrightarrow \quad\left[\mathrm{Al}(\mathrm{OH})_{3}\right]_{\mathrm{n}}$
$\leftarrow$
$(\mathrm{AlO})_{\mathrm{n}}(\mathrm{SiO})_{\mathrm{n} / 2}(\mathrm{OH})_{2 \mathrm{n}}$
Íon livre
Hidróxido de $\mathrm{Al}$ amorfo
Hidroxialuminossilicatos

Sousa Junior (2019), ao estudar o efeito tóxico do Al em plantas jovens de cana-de-açúcar constatou que adubação silicatada reduz os efeitos do estresse que mitigam o crescimento vegetativo (Figura 2). Além disso, o autor destaca que sob a presença de Si as plantas incrementaram o crescimento da parte aérea e do sistema radicular. 
Figura 2. Massa seca da parte aérea (MSPA) e massa seca da raiz (MSR) de plantas jovens de cana-de-açúcar sob concentrações de $\mathrm{Al}^{3+}$, na ausência e presença de Si.

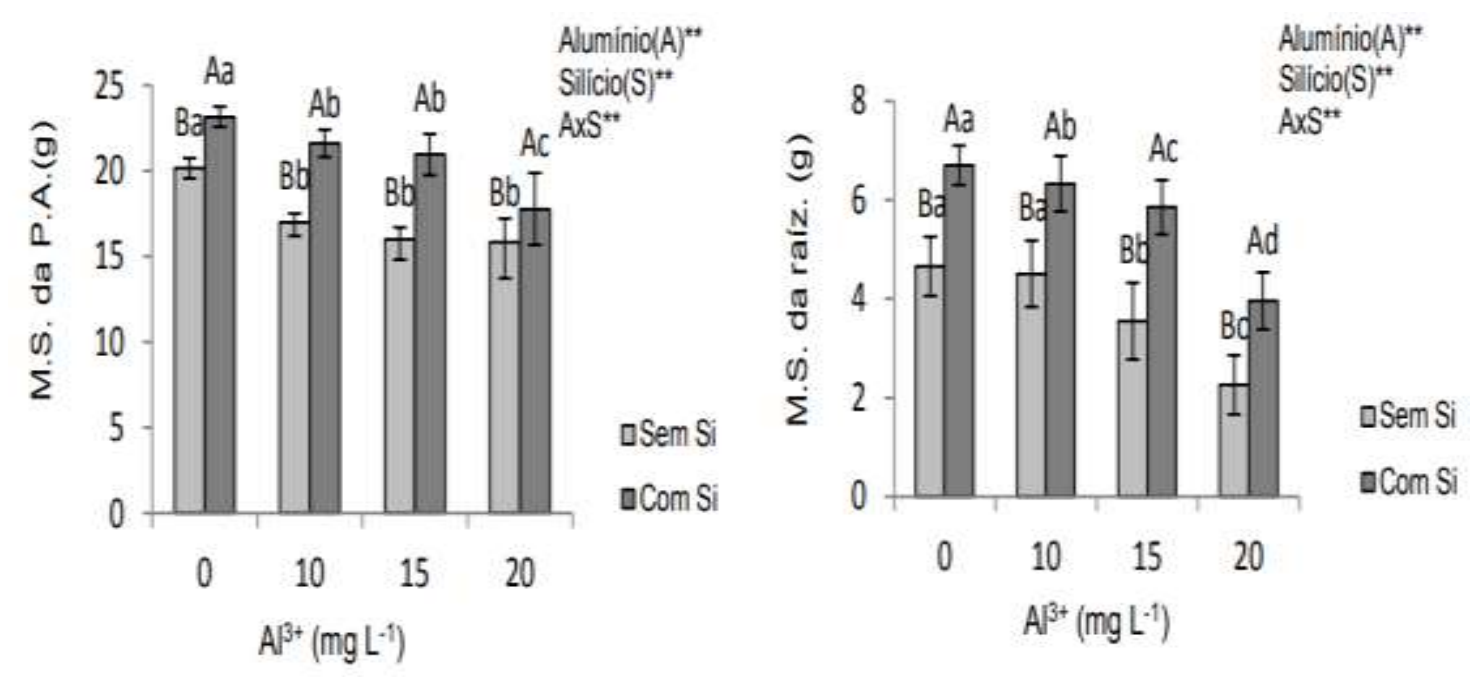

Fonte: Sousa Junior (2019).

A redução da peroxidação lipídica nas membranas via estimulação não-enzimática, pode explicar a tolerância das plantas a metais pesados, incluindo o $\mathrm{Al}$ (Liang et al., 2007). O Si também apresentou efeito mitigador em espécies vegetais, como o milho (Giongo \& Bohnen, 2011), arroz (Freitas et al., 2015) e batata (Dorneles et al., 2016).

Os benefícios do Si têm sido estudados no enfrentamento tanto da descontaminação de solos por cádmio $(\mathrm{Cd})$, como também, na diminuição do efeito tóxico deste elemento para as espécies vegetais. Além de ocasionar aumento do $\mathrm{pH}$, a presença dos íons silicatos no sistema solo, tem a capacidade de complexar o $\mathrm{Cd}$ e retê-lo, dificultando sua absorção pelo sistema radicular das plantas (Sommer et al., 2006). Assim, o Si induz resistência reduzindo a absorção de íons tóxicos, através de sua deposição na endoderme do sistema radicular (Ma \& Guo, 2014), devido a um bloqueio físico na rota apoplástica que restringe a absorção de Cd (Tabela 2), impedindo a translocação para parte aérea vegetal (Cunha \& Nascimento, 2009).

O Si que está depositado na parede celular das folhas e do sistema radicular do arroz apresenta afinidade pelo Cd (Wang et al., 2000). Tal espécie é considerada planta acumuladora do elemento podendo significar alta redução do Cd por apoplástico, assim, o processo de difusão entre as células, torna-se dificultado, através da formação da sílica coloidal, que é altamente insolúvel, havendo um possível isolamento do Cd nas células das raízes (Oliveira, 2009). 
Tabela 2. Acúmulo de Cd em plantas de arroz submetidas a deferentes doses de Cd, na presença de silício (+Si) e ausência de silício (-Si).

\begin{tabular}{|c|c|c|c|c|c|c|}
\hline \multirow{2}{*}{$\begin{array}{l}\text { Concentração de Cd } \\
\text { na solução nutritiva } \\
\left(\boldsymbol{\mu m o l} \mathbf{L}^{-1}\right)\end{array}$} & \multicolumn{2}{|c|}{ Parte aérea } & \multicolumn{2}{|c|}{ Raíz } & \multicolumn{2}{|c|}{ Grão com casca } \\
\hline & $-\mathrm{Si}$ & $+\mathrm{Si}$ & $-\mathrm{Si}$ & $+\mathrm{Si}$ & $-\mathrm{Si}$ & $+\mathrm{Si}$ \\
\hline & & -------. & $----C c$ & $\left(n \mathrm{ta}^{-1}\right)$ & ------- & \\
\hline 0,00 & $0,06 \mathrm{a}$ & $0,01 \mathrm{a}$ & $0,03 \mathrm{a}$ & $0,02 \mathrm{a}$ & $0,04 \mathrm{a}$ & $0,006 b$ \\
\hline 0,45 & $0,13 \mathrm{a}$ & $0,11 \mathrm{a}$ & $0,20 \mathrm{a}$ & $0,20 \mathrm{a}$ & $0,06 \mathrm{a}$ & $0,04 \mathrm{a}$ \\
\hline 4,50 & $0,60 \mathrm{a}$ & $0,44 b$ & $1,85 \mathrm{a}$ & $0,84 b$ & $0,15 \mathrm{a}$ & $0,14 \mathrm{a}$ \\
\hline 9,00 & $1,28 \mathrm{a}$ & $0,58 b$ & $4,98 \mathrm{a}$ & $3,12 b$ & $0,18 \mathrm{a}$ & $0,15 \mathrm{a}$ \\
\hline 22,52 & $1,67 \mathrm{a}$ & $0,92 b$ & $5,20 \mathrm{a}$ & $3,87 b$ & $0,20 \mathrm{a}$ & $0,13 b$ \\
\hline 45,05 & $1,15 \mathrm{a}$ & 0,94 & 6,58 & $4,57 \mathrm{~b}$ & $0,26 a$ & $0,09 b$ \\
\hline
\end{tabular}

Fonte: Oliveira (2009).

Em estudo realizado por Pereira (2017) avaliou-se o efeito do Si sobre as características fisiológicas de plantas de feijão (Vigna unguiculata) sob estresse provocado pelo Cd. A autora concluiu que mediante a ação do Si houve atenuação do estresse provocado pelo Cd. Com relação a absorção de luz no fotossistema II (FII), houve aumento no rendimento quântico efetivo e na taxa de transporte de elétrons. Concluiu-se ainda que, as plantas sob estresse provocado pelo $\mathrm{Cd}$ na presença de $\mathrm{Si}$, apresentaram aumento na atividade de enzimas antioxidantes.

\section{Silício e o estresse por deficiência de micronutrientes}

Alguns autores recentemente têm se dedicado ao estudo dos efeitos benéficos causados pelo Si em resposta a deficiência por micronutrientes, como ferro (Fe) e zinco (Zn) (Hernandez-Apaolaza, 2014). Em estudo realizado por Gonzalo et al. (2013), constatou-se que a aplicação de Si foi capaz de atenuar o estresse provocado em função da deficiência de Fe em plantas de soja onde a adição de Si provocou atraso na clorose. Além disso, em plantas de arroz o Si promoveu maior distribuição de Zn do sistema radicular para a parte aérea da planta (Mehrabanjoubani et al., 2015).

Em plantas de pepino a aplicação do Si culminou com a redução dos sintomas causados pela deficiência de zinco e manganês, ocasionando aparecimento de manchas necróticas, efeito causado, provavelmente, através do aumento do efeito antioxidante nos tecidos da planta (Bityutskii et al., 2014). Em plantas de sorgo o Si mitigou os efeitos deletérios ocasionados pela deficiência de Mn, sendo a aplicação via radicular mais efetiva que a foliar, trazendo resultados positivos para maior atividade fotossintética, maior área foliar, matéria seca e maior eficiência no uso de Mn (Oliveira, 2017).

\section{Silício e sua relação com o estresse biótico}

\section{Silício e o controle de fitopatógenos}

Diversos estudos comprovam que as plantas respondem de forma positiva a adubação silicatada para supressão de doenças (Tabela 3), essas respostas podem ser a nível físico, químico e molecular. Silva et al. (2012) destacam que o Si promove uma barreira física pré-infecção, esse efeito acontece através da deposição deste elemento na parede celular das plantas, pela formação de uma dupla camada de sílica amorfa e salificação das células, efeito que ocasiona dificuldade a 
penetração de microrganismos fitopatogênicos (Rodrigues et al., 2003). Além disso, barreiras pós-infecção também podem ser formadas no local de entrada destes organismos através de papilas (Pereira et al., 2009).

O Si pode atuar como sinalizador bioquímico, construindo barreiras através da formação de compostos fenólicos e aumento na atividade de enzimas que atuam no sistema de proteção da planta, como quitinases, peroxidases, lipoxigenases, polifenoloxidases, $\beta$-1,3-glucanases e fenilalanina amônia-liases (Burtet, 2018). Pode ainda atuar a nível molecular através da regulação de genes envolvidos no sistema de defesa das plantas (Wang et al., 2017).

Algumas hipóteses são comumente aceitas pela comunidade científica para explicar os efeitos benéficos do Si na supressão de doenças de plantas, há estudos na literatura da ação benéfica do Si em monocotiledôneas e dicotiledôneas, a nível de ação desse elemento em características físicas e químicas. Dessa forma, o Si pode propiciar a polimerização através da deposição de ácido salić́lico, formando uma dupla camada de sílica amorfa abaixo da cutícula (Yoshida, 1965), silicificação de células da epiderme (Ishiguro, 2001) e fortificação das células da epiderme vegetal (Kim et al., 2001). Além disso, enzimas que tem relação com a patogênese de plantas, tem sua atividade aumentada sob efeito da adubação silicatada (Jones, 1984) e acúmulo de compostos fenólicos (Rodrigues et al., 2004).

Alguns autores estudaram os efeitos benéficos do Si no controle de fitonematóides em dicotiledôneas. Dutra et al. (2014) ao estudarem a aplicação de silicato de cálcio na cultura do feijão numa dose de $4 \mathrm{~g} \mathrm{dm}^{-3}$, obtiveram resultados significativos na redução do fator de reprodução (FR) de Meloidogyne javanica e M. incógnita. Na cultura da soja, Freire (2007) ao aplicar uma dose de $1,6 \mathrm{~mL} \mathrm{dm}^{-3}$ de silicato de potássio houve redução de $75 \%$ na reprodução do nematoide de cistos (Heterodera glycines). Em fitonematóides os indutores de resistência são resultado da paralisação ou aumento do ciclo de parasitismo, influindo no estímulo da eclosão de ovos, induzido na manutenção dos sítios de alimentação (Cook, 1991). Chérif et al. (1994) destacam que, aparentemente, o Si induz os mecanismos de defesa da planta, quando ela é atacada pelo patógeno, provocando rápida resposta de defesa.

Tabela 3. Efeito do silício na supressão de doenças de plantas.

\begin{tabular}{|c|c|c|c|}
\hline Doença & Patógeno & Cultura & Fonte \\
\hline $\begin{array}{l}\text { Mancha branca do } \\
\text { milho }\end{array}$ & Pantoea ananatis & Milho & Burtet (2018) \\
\hline Antracnose & Colletrotichum truncatum & Feijão fava & Nascimento et al. (2017) \\
\hline Antracnose & $\begin{array}{l}\text { Colletrotichum } \\
\text { lindemuthianum }\end{array}$ & Feijão & Vedovatto (2017) \\
\hline Míldio & Bremia lactucae raça $S P B l: 01$ & Alface & Allves et al. (2019) \\
\hline Brunose & Pyricularia grisea & Arroz & Santos et al. (2003) \\
\hline Mancha de Turcicum & Exserohilium turcicum & Milho & Alves et al. (2020) \\
\hline Micosferela & & Morango & Kowal et al. (2020) \\
\hline & Mycosphaerella fragariae & & \\
\hline Nematoide das galhas & Meloidogyne javanica & Pepino & Santos et al. (2018) \\
\hline Antracnose & Colletrotichum gloeosporioide & Abacate & Anderson et al. (2005) \\
\hline Cercospora & Cercospora caffeicola & Café & Pozza et al. (2004) \\
\hline
\end{tabular}

Fonte: Autores (2021).

A indução de resistência causada através da adubação silicatada tem trazido resultados satisfatórios no controle de doenças em distintas espécies agrícolas, sendo a prática incluída nos programas de manejo integrado (Pozza et al., 2015). A 
aplicação de silicato de potássio na cultura da soja, foi capaz de reduzir a severidade da ferrugem asiática agente causal Phakopsora pachyrhizi (Pereira et al., 2009). A utilização de silicato de potássio também influenciou de maneira positiva no aumento de lignina nas folhas de soja, que constitui uma barreira física levando à supressão do patógeno (Cruz et al., 2013).

Em trabalho realizado por Anjos et al. (2014) avaliando fontes de $\mathrm{Si}$ no controle de mancha bacteriana (Xanthomonas spp.) na cultura do tomateiro, concluíram que o silício coloidal não foi eficiente no controle do patógeno, entretanto, as doses de 30, 40 e $50 \mu \mathrm{L}^{-1}$ de silicato de potássio inibiram o crescimento da bactéria in vitro e as concentrações de 40 e $50 \mathrm{~g} \mathrm{~L}^{-1}$ reduziram o índice de doença em experimento conduzido em casa de vegetação.

\section{Silício e o controle de insetos-praga}

Diversos autores em trabalhos realizados com Si, apontam a atuação direta deste elemento com elevados índices de redução a ataques de insetos-praga. Isso ocorre devido ao aumento da resistência física pela sua deposição na parede celular, promovendo maior rigidez dos tecidos epidérmicos (Tabela 4). Existem relatos também da ocorrência de menor digestibilidade dos tecidos vegetais consumidos por estes insetos e produção de enzimas do sistema defensivo das plantas (Portela \& Silva, 2018). Além disso, Alcantra et al. (2010) destaca a redução no crescimento dos insetos e sua menor taxa reprodutiva.

Tabela 4. Número de tricomas e dureza foliar em plantas de Davilla elliptica submetidas a adubação silicatada (silicato de cálcio) e magnésio.

\begin{tabular}{ccc}
\hline Tratamento & Número de tricomas & Dureza foliar (kgf) \\
\hline Sem Si & $124 \mathrm{a}$ & $209 \mathrm{a}$ \\
$\mathrm{Com} \mathrm{Si}$ & $171 \mathrm{~b}$ & $224 \mathrm{~b}$ \\
\hline
\end{tabular}

Fonte: Korndörfer (2006).

São variadas as culturas de importância agrícola citadas na literatura que utilizam o $\mathrm{Si}$, como forma alternativa ao controle de insetos. Ao estudar a influência do Si na cultura do milho Goussain et al. (2002), constataram uma taxa de mortalidade de 36\% de indivíduos de Spodoptera frugiperda e 21\% quando o inseto estava no sexto ínstar, efeito que pode estar relacionado com a menor taxa de alimentação. Assim, os autores atribuem este efeito ao desgaste das mandíbulas deste lepidóptero, ocasionado devido a rigidez provocada pelo Si nas folhas de milho.

Da mesma forma, Marchioro et al. (2019) observaram aumento na mortalidade e canibalismo (Figura 4) em Spodoptera frugiperda e diminuição populacional quando a cultura do milho recebeu adubação silicatada. Esse efeito está relacionado a menor palatabilidade das folhas, causando estresse alimentar ao inseto em função da deposição do Si nas folhas do milho (GOUSSAIN et al., 2002). 
Figura 4. Percentual médio \pm EP de Mortalidade (A) e Canibalismo (B) de lagartas de S. frugiperda alimentadas com folhas de milho, com ou sem adição de silício, ao final do $2^{\circ}$ instar.

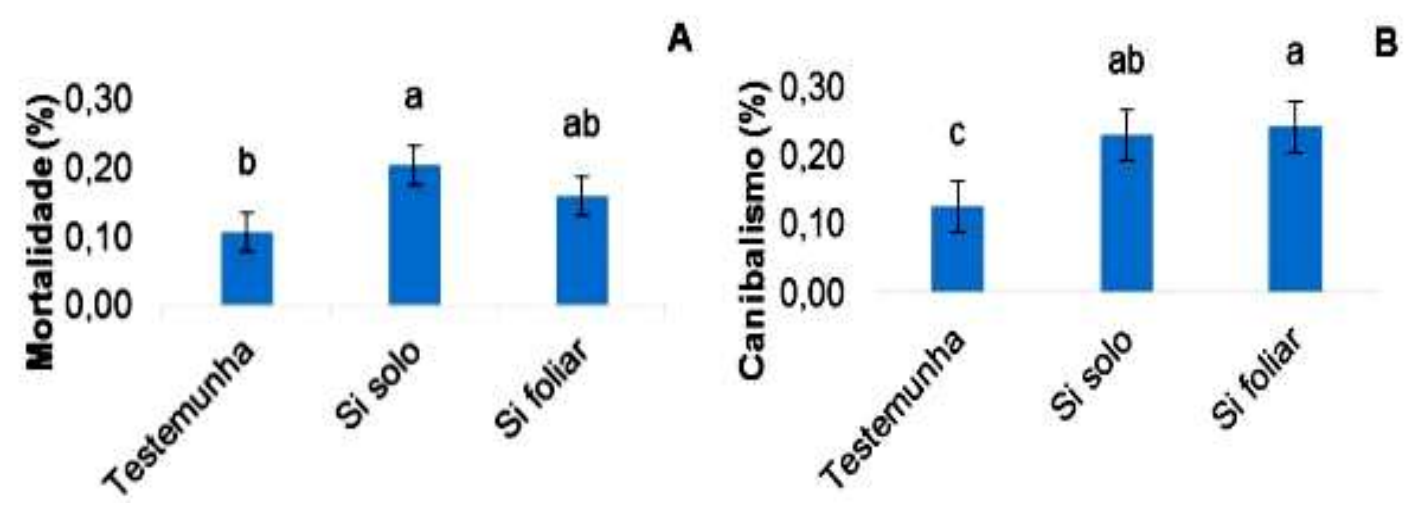

Fonte: Marchioro et al. (2019).

O Si também pode atuar diminuindo os efeitos deletérios causados por larvas (Liriomyza spp.), reduzindo as galerias provocadas por estes insetos em plantas de batata inglesa em sistema orgânico sob efeito de adubação silicatada (Goussain et al., 2002). Em trabalho conduzido por Correa et al. (2005), com a cultura do pepino utilizando como fonte de Si o silicato de cálcio via solo e foliar, os autores constataram diminuição na ovoposição, aumento do ciclo biológico e mortalidade na fase de ninfa da mosca-branca (Bemisia tabaci biótipo B).

\section{Considerações Finais}

Diante das informações agrupadas na presente revisão de literatura, é possível concluir que o Si, apesar de não ser considerado um elemento essencial para o desenvolvimento e crescimento das plantas, proporciona inúmeros benefícios a essas, destacando-se, maior tolerância aos estresses bióticos e abióticos, por atuar diretamente na fisiologia vegetal e em processos químicos importantes no solo.

Dessa forma, diversos estudos vêm sendo desenvolvidos buscando identificar qual a dose e o momento ideal para se realizar adubação silicatada, qual a fonte mais adequada e a forma de aplicação. No Brasil, diversos são os pesquisadores envolvidos nessa aérea, trabalhando com culturas de interesse econômico e alimentar.

Ainda assim, necessário se faz o direcionamento da pesquisa em culturas acumuladoras e não-acumuladoras, buscando solucionar as possíveis divergências e desenvolvimento de cultivares responsivas, além do estudo entre a interação do Si como elemento benéfico e outros elementos que sejam essenciais as plantas, assim, otimizando a utilização do Si.

\section{Referências}

Adatia, M. H. \& Besford, R. T (1986). The effects of silicon on cucumber plants grown in recirculating nutrient solution. Annals of Botany, 58, 343-351.

Ahmad, R., Zaheer, S. \& Ismail, S (1992). Role of silicon in salt tolerance of wheat (Tritium aestivum L.). Plant Science, 85(1), 43-50.

Alcantra, E., Moraes, J. C. \& Antonio, A (2010). Efeito de indutores da resistência e cultivares de algodão no comportamento de Aphis gossypii. Revista Ciência Agronomica, 41(4),1-6.

Alcarde, J. A. \& Rodella, A. A (2003). Qualidade e legislação de fertilizantes e corretivos. In: CURI, N. et al. (Eds.). Tópicos em Ciência do Solo. Viçosa, MG: Sociedade Brasileira de Ciência do Solo. 3, .291-334.

Alovisi, A. M. T., Neto, Antonio E. F., Carneiro, L. F., Curi, N. \& Alovisi, A. A (2014). Silicon-phosphorus interactions in soils cultivated with bean plants. Acta Scientiarum Agronomy, 36(1),.79-86.

Anjos, T. V. D., Tebaldi, N. D., Mota, L. C. B. M. \& Coelho, L (2014). Fontes de silício no controle da mancha bacteriana (Xanthomonas spp.) do tomateiro. Summa Phytopathologica, 40(4), 365-367. 
Anjum, S. A., Xie, X.Y., Wang, L. C., Saleem, M. F., Man, C. \& Lei, W (2011). Morphological, physiological and biochemical responses of plants to drought stress. African Journal of Agricultural Research, 6(9), 2026-2032.

Baliza, D. P., Ávila, F. W., Carvalho, J. G., Guimarães, R. J., Passos, A. M. A. \& Pereira, V. A (2010). Crescimento e nutrição de mudas de cafeeiro influenciadas pela substituição do potássio pelo sódio. Coffee Science, 5(3), 272-282.

Barbosa Filho, M. P., Snyder, G. H., Fageria, N. K., Datnoff, L. E. \& Silva, O. F (2001). Silicato de cálcio como fonte de silício para o arroz de sequeiro. Revista Brasileira de Ciência do Solo, 25, 325-330.

Bityutskii, N., Pavlovic, J., Yakkonen, K., Maksimović, V. \& Nikolic, M (2014). Contrasting effect of silicon on iron, zinc and manganese status and accumulation of metal-mobilizing compounds in micronutrient-deficient cucumber. Plant Physiology and Biochemistry, 74, 205-211.

Bradbury, M. \&Ahmad, R (1990). The effect of silicon on the growth of Prosopis juliflora growing in saline soil. Plant and Soil, 125, 71-74.

BRASIL Decreto n. 4954 (2004). Aprova o regulamento da lei 6894 de 16 de janeiro de 1980, que dispõe sobre a inspeção e fiscalização da produção e do comércio de fertilizantes, corretivos, inoculantes ou biofertilizantes destinados à agricultura, e dá outras providências. Normas Jurídicas (Texto Integral) DEC 004954, 14 jan., p. 27.

Burtet, G. W (2018). Silício e Azospirillum brasilense associado ao controle químico sobre a severidade de Pantoea ananatis em milho. 2018. Dissertação de mestrado, Universidade Federal de Santa Maria.

Camargo, M. S (2016). Efeito do silício na tolerância das plantas aos estresses bióticos e abióticos. Informações Agronômicas, 155, 1-9.

Camargo, M. S., Korndörfer, G. H., Corrêa, G. F., Pereira, H. S., Barbosa, D. S. \& Resende, R. H (2005). Extratores de silício solúvel em solos: influência do calcário e fósforo. Biosci. J., 21, 9-19.

Camargo, M. S., Pereira, H. S., Korndörfer, G. H., Queiroz, A. A. \& Reis, C. B (2007). Soil reaction and absorption of silicon by rice. Scientia Agricola64, 176-180.

Cantuário, F. S., Luz, J. M., Pereira, A. I., Salomão, L. C. \& Rebouças, T. N (2014). Podridão apical e escaldadura em frutos de pimentão submetidos a estresse hídrico e doses de silício. Horticultura Brasileira, 32, 215-219.

Castro, G. S. A. \& Crusciol, C. A. C (2013). Effects of superficial liming and silicate application on soil fertility and crop yield under rotation. Geoderma, Amsterdam, 195-196, 234-242.

Chérif, A., Asselin, A. \& Bélanger, R. R (1994). Defense responses induced by soluble silicon in cucumber roots infected by Pythium spp. Phytopathology, 84, 236-242.

Cook, R (1991). Resistance in plants to cyst and root-knot nematodes. Agricultural Zoology Reviews, 4, 231-239.

Correa, R. S., Moraes, J. C., Auad, A. M. \& Carvalho, G. A (2005). Silicon and acibenzolar-S-methyl as resistance inducers in cucumber, against the whitefly Bemisia tabaci (Gennadius) (Hemiptera: Aleyrodidae) biotype B. Neotropical Entomology, 34, 429-433.

Crusciol, C. A. C., Pulz, A. L., Lemos, L. B., Soratto, R. P ; Lima, G. P. P (2009). Effects of silicon and drought stress on tuber yield and leaf biochemical characteristics in potato. Crop Science, 49, 949-954.

Cruz, M. F. A. D., Rodrigues, F. Á., Polanco, L. R., Curvêlo, C. R. D. S., Nascimento, K. J. T., Moreira, M. A. \& Barros, E. G (2013). Inducers of resistance and silicon on the activity of defense enzymes in the soybean-Phakopsora pachyrhizi interaction. Bragantia, 72, 162-172.

Cunha, K. P. V. \& Do Nascimento, C. W. A (2009). Silicon effects on metal tolerance and structural changes in maize (Zea mays L.) grown on a cadmium and zinc enriched soil. Water, air, and soil pollution, 197323.

Curvêlo, C. R. S., Rodrigues, F. Á., Pereira, L. F., Silva, L. C., Damatta, F. M. \& Berger, P. G (2013). Leaf gas exchange and oxidative stress on cotton plants supplied with silicon and infected by Ramularia areola. Bragantia, 72 346-359.

Dechen, A. R. \& Nachtigall, G (2006). Ribeiro. Elementos requeridos à nutrição de plantas. In: Novais, R. F., Alvarez V., V. H., Barros, N. F., Fontes, R. L. F., Cantarutti, R. B. \& Neves, J. C. L. Fertilidade do Solo, cap. 3, p. 91-133.

Dorneles, A. O. S., Pereira, A. S., Rossato, L. V., Possebom, G., Sasso, V. M., Bernardy, K. \& Tabaldi, L. A (2016). Silicon reduces aluminum content in tissues and ameliorates its toxic effects on potato plant growth. Ciência Rural, 46, 506-512.

Dutra, M. R., Garcia, A. I. A., Paiva, B. R. T. L., Rocha, F. S. \& Campos, V. P (2004). Efeito do silício aplicado na semeadura do feijoeiro no controle de nematoides das galhas. Fitopatologia Brasileira, Brasília, 29, 172.

Epstein, E (1999). Silicon. Annual Review of Plant Physiology and Plant Molecular Biology, Palo Alto, 50, 641-649.

Epstein, E. \& Bloom, A. J (2004). Mineral nutrition of plants: principles and perspectives. Sunderland: Sinauer Associates, p. 418.

Faria, L. De A. \& Karp, F. H (2015). Selênio: um elemento essencial ao homem e aos animais e benéfico as plantas. Informações Agronômicas, $\mathrm{n}^{\circ}$ 149, p. $17-$ 22 .

Fatima, R. T., Silva, I. J., Guerrero, A. C., Lima, G. S., Pádua, S., L. \& Lacerda, C. N (2020). Fitomassas de pimentão cultivado sob lâminas de irrigação e doses de silício foliar. In: INOVAGRI Meeting Virtual.

Felisberto, G (2018). Silício na mitigação de estresse por deficiência de zinco em plantas de arroz e soja. Tese de doutorado, Universidade Estadual Paulista. 
Freire, E. S (2007). Controle dos nematoides de galhas (Meloidogyne spp.) e do cisto (Heterodera glycines) com silicatos. Dissertação, Universidade Federal de Lavras - Lavras, 2007.

Freitas, L. B., Coelho, E. M., Maia, S. C. M. \& Silva, T. R. B (2011). Adubação foliar com silício na cultura do milho. Rev. Ceres. 58 , $262-267$.

Freitas, L. B., Fernandes, D. M. \& Maia, S. C. M (2015). Silicon on the mineral nutrition and aluminum accumulation in upland rice plants. Pesqui. Agropecu. Trop, 45 440-448.

Gao, X., Zou, C., Wang, L. \& Zhang, F (2006). Silicon decreases transpiration rate and conductance from stomata of maize plants. Journal of Plant Nutrition, 29, 1637-1647.

Gill, S. S. \& Tuteja, N (2010). Reactive oxygen species and antioxidant machinery in abiotic stress tolerance in crop plants. Plant Physiology and Biochemistry, Amsterdã, 48, 909-930.

Giongo, V. \& Bohnen, H (2011). Relação entre alumínio e silício em genótipos de milho resistente e sensível a toxidez de alumínio. Bioscience Journal, 27, 348- 356 .

Gong, H., Zhu, X., Chen, K., Wang, S. \& Zhang, C (2005). Silicon alleviates oxidative damage of wheat plants in pots under drought. Plant Science, 169, 321.

Gonzalo, M. J., Lucena, J. J. \& Hernandez-Apaolaza, L (2013). Effect of silicon addition on soybean (Glycine max) and cucumber (Cucumis sativus) plants grown under iron deficiency. Plant Physiol, 70, 455-461.

Goussain, M. M., Moraes, J. C., Carvalho, J. G., Nogueira, N. L. \& Rossi, M. L (2002). Efeito da aplicação de silício em plantas de milho no desenvolvimento biológico de lagarta do-cartucho Spodoptera frugiperda (J. E. Smith) (Lepidoptera: Noctuidae). Neotropical Entomology, 31, 305-310.

Guerra, C. A., Marchetti, M. E., Robaina, Antonio, D., Souza, L. C. F., Gonçalves, M. C. \& Novelino, J. O (2006). Qualidade fisiológica de sementes de soja em função da adubação com fósforo, molibdênio e cobalto. Acta Sci. Agron. 28, 1-7.

Gunes, A., Inal, A., Bagci, E. G. \& Coban, S (2007). Influence of silicon on antioxidant mechanisms and lilip peroxidation in chickpea (Cicer arietinum L.) cultivars under drought stress. Journal of Plant Interactions, 2, 105-113.

Guo, Y. \& Marschner, H (2001). Uptake, distribuition, and binding of cadmium and nickel in different plant species. In: Ferreira, M. E. Micronutrientes e elementos tóxicos na agricultura. Jaboticabal: CNPq/FAPESP/POTAFOS, p. 58-70.

Hernandez - Apaolaza, L (2014). Can silicon partially alleviate micronutrient deficiency in plants? A review. Planta, 240, 447-458.

Hodson, M. J. \& Sangster, A. G (1999). Aluminium/silicon interactions in conifers. Journal of inorganic biochemistry, 76, 89-98.

Ishiguro, K (2001). Review of research in Japan on the roles of silicon in conferring resistance against rice blast. pp. 277-291. In: Silicon in Agriculture, Datnoff, L. E.; Snyder, G. H.; Körndorfer, G. H. (Eds.). Elsevier Science, The Netherlands.

Jones, D. H. Phenylalanine ammonia-lyase: regulation of its induction, and its role in plant development. Phytochemistry, 23, 1349-1360

Korndorfer G. H., Pereira H. S. \& Camargo M. S. Silicato de cálcio e magnésio na agricultura. Uberlândia: UFU/ICIAG, 3p (GPSi-ICIG-UFU). Boletim Técnico, $\mathrm{n}^{\circ} 01,2002$.

Korndörfer, A. P. (2006). A importância do silício nas relações entre herbivoros e Davilla elliptica (Dilleniaceae) St. Hil no cerrado. Dissertação de mestrado, Universidade Federal de Uberlândia.

Korndörfer, G. \& Souza, S. R. Elementos benéficos. In: FERNANDES, Manlio Silvestre; SOUZA, Sônia Regina de; SANTOS, Leandro Azevedo (2018). Nutrição Mineral de Plantas, cap. 15, 563-599.

Lana, R. M. Q., Korndörfer, G. H., Zanão Júnior, L. A., Silva, A. F. \& Lana, A. M. Q (2003). Efeito do silicato de cálcio sobre a produtividade e acumulação de silício no tomateiro. Biosci. J., 19, 15-20.

Leitzke, I. D., Brunes, A. P., Dias, L. W., Fin, S. S. \& Albuquerque, A. C. S (2014). Aplicação de silício via solo para diminuição do estresse salino. In: XXII Congresso de iniciação científica da universidade federal de pelotas.

Liang, Y. C., Sun, W. C. \& Si, J (2005). Effects of foliar- and root-applied silicon on the enhancement of induced resistance to powdery mildew in Cucumis sativus. Plant Pathology, 54, 678-685.

Liang, Y. C., Sun, W., Zhu, Y. G. \& Christie, P (2007). Mechanisms of silicon mediated alleviation of abiotic stress in higher plants: a review. Environmental Pollution, 147, 422-428.

Ludwig, F., Behling, A. \& Schmitz, J. A. K (2015). Silício na produção e qualidade fitossanitária do tomate (Lycopersicum esculentum). Scientia Agraria Paranaensis, 14, 60-66.

Ma, J. F \& Yamaji, N (2006). Silicon uptake and accumulation in higher plants. Trends in Plant Science, 11, 392-397.

Ma, J.F., Miyake, Y. \& Takahashi, E (2001). Silicon as a beneficial element for crop plants. In: DATNOFF, L.E.; SNYDER, G.H.; KORNDÖRFER, G.H. Silicon in agriculture. Amsterdam: Elsevier. p.17-39.

Malavolta, E (2006). Manual de nutrição mineral de plantas. Editora Ceres, p. 631.

Manivannan, A., Soundarajan, P., Munner, S., Ko, C. H. \& Jeong, B. R (2016). Silicon Mitigates Salinity Stress by Regulating the Physiology, Antioxidant Enzyme Activities, and Protein Expression in Capsicum annuum'Bugwang'. BioMed Research International, 1, 1-14. 
Marchioro, S. T., Fernandes, A. P., Pomari, A. C. P. \& Sebben, M. F (2019). Mortalidade e Canibalismo de Spodoptera frugiperda em Milho Tratado com Silício. Cadernos de Agroecologia,

Martinez, R. A. S., Rezende, P. M., Alvarenga, A. A., Andrade, M. José B. \& Passos, A. M. A (2009). Doses and forms of selenium application on the culture of soybean. Ciência e Agrotecnologia, 33, 698-704.

MELO, S. P., Monteiro, F. A. \& Manfredini, D (2007). Silicate and phosphate combinations for marandu pallisa degrass growing on an oxisol. Scientia Agrícola, 64, 275-281.

Miranda, J. R. P., Carvalho, J. G., Santos, D. R., Freire, A. L. O., Bertoni, J. C., Melo, J. R. M. \& Caldas, A. L (2002). Silício e cloreto de sódio na nutrição mineral e produção de matéria seca de plantas de moringa (Moringa oleifera Lam.). Revista Brasileira de Ciência do Solo, 26, 957-965.

Moreira, A. R., Fagan, E. B., Martins, K. V. \& Souza, C. H. E (2010). Resposta da cultura de soja a aplicação de silício foliar. Biosci. J., 26, 413-423.

Nascimento, E. H. S., Ruppenthal, V., Nascimento, I. L., Silva, M. L. S., Sabóia, C. B. \& Eneas-Filho, J (2014). Utilização de silício na atenuação dos efeitos do estresse salino em plantas de sorgo. In: II INOVAGRI International Meeting.

Neumann, D. \& Nieden, U (2001). Silicon and heavy metal tolerance of higher plants. Phytochemistry, 56, 685-692.

Nolla, A., Korndörfer, G. H., Silva, T. R. B., Muniz, A. S. \& Silva, M. A. G (2013). Correção da acidez de um neossolo submetido à aplicação de carbonato e silicato de cálcio. Journal of Agronomic Sciences, 2, 113-120.

Nunes, A. M. C., Lima N. L. R., Rodrigues, A. J. O. \& Uchôa, K. S. A (2019). Silício na tolerância ao estresse hídrico em tomateiro. Revista Científica Rural21, 239-258.

Oliveira, L. A (2009). Silício em plantas de feijão e arroz: absorção, transporte, redistribuição e tolerância ao cádmio. Tese de Doutorado, Universidade de São Paulo.

Oliveira, R. L. L (2017). Aplicação de silício na fisiologia, na produção e na mitigação de estresse causado pela deficiência de manganês em plantas de sorgo granífero. Dissertação de mestrado, Universidade Estadual Paulista.

Parida, A. K. \& Das, A. B (2004). Effects of $\mathrm{NaCl}$ stress on nitrogen and phosphorous metabolism in a true mangrove Bruguiera parviflora grown under hydroponic culture. Journal of Plant Physiology, 161, 921-928.

Pereira Júnior, P., Rezende, P. M., Malfitano, S. C., Lima, R. K., Corrêa, L. V. T. \& Carvalho, E. R (2010). Efeito de doses de silício sobre a produtividade e características agronômicas da soja. Ciência e Agrotecnologia, 34, 908-913.

Pereira, A. S., Shitsuka, D. M., Parrreira, F. J. \& Shitsuka, R (2018). Metodologia da pesquisa científica. UFSM, Universidade de Santa Maria.

Pereira, H. S., Vitti, G. C. \& Korndorfer, G. H (2003). Comportamento de diferentes fontes de silício no solo e na cultura do tomateiro. Rev. Bras. Ciênc. Solo, 27, 101-108.

Pereira, S. C., Rodrigues, F. A., Carré-Missio, V., Oliveira, M. G. A. \& Zambolim, L (2009). Aplicação foliar de silício na resistência da soja à ferrugem e na atividade de enzimas de defesa. Tropical Plant Pathology, 34, 164-170.

Pereira, T. S (2017). Efeito do silício sobre fluorescência de clorofilas, trocas gasosas e enzimas em Vigna unguiculata (L.) sob estresse por cádmio. Trabalho de conclusão de curso, Universidade Federal Rural da Amazônia.

Portela, G. L. F. \& Silva, P. R. R. (2018). Silício como indutor de resistência no controle do pulgão Aphis craccivora Koch, 1854 em fava Phaseolus lunatus. Tese de doutorado, Universidade Federal do Piauí.

Pozza, A. A. A., Alves, E., Pozza, E. A., Carvalho, J. G., Montanari, M., Guimarães, P. T. G. \& Santos, D. M (2004). Efeito do silício no controle da cercosporiose em três variedades de cafeeiro. Fitopatologia Brasileira, 29, 185-188.

Pozza, E. A., Pozza, A. A. A. \& Botelho, D. M. S (2015). Silicon in plant disease control. Revista Ceres, 62, -331.

Pulz, A. L., Crusciol, C. A. C., Lemos, L. B. \& Soratto, R. P (2008). Influência de silicato e calcário na nutrição, produtividade e qualidade da batata sob deficiência hídrica. Revista Brasileira de Ciência do Solo, 32, 1651-1659.

Quaggio, J. A (2000). Acidez e calagem em solos tropicais. 1 ed. Campinas: Instituto Agronômico, 111p.

Ramos, L. A., Nolla, A., Korndörfer, G. H., Pereira, H. S. \& Camargo, M. S (2006). Reactivity of soil acidity correctives and conditioners in lysimeters. Revista Brasileira de Ciência Solo, 30, 849-857.

Raven, J. A. Silicon transport at the cell and tissue level. In: DATNOFF, L. E.; SNYDER, G. H.; KORNDÖRFER, G. H (2001). (Ed). Silicon Agriculture. Amsterdam: Elsevier41-55.

Reis, J. J. D., Alovisi, A. M. T., Ferreira, J. A. A., Alovisi, A. A. \& Gomes, C (2013). Attributes of chemical soil and production of sugar cane in response to calcium silicate. Rev. de Ciências Agrárias, 36, 3-9.

Ribeiro, R. V., Silva, L., Ramos, R. A., Andrade, C. A., Zambrosi, F. C. B. \& Pereira, S. P (2011). High soil silicon concentrations inhibit coffee root growth without affecting leaf gas exchange. Rev. Bras. Ciênc. Solo, 35 939-948.

Rodrigues, F. A (2003). Ultrastructural and cytochemical aspects of silicone-medianted rice blast reistance. Phytopathology, 93, 535-546. 
Research, Society and Development, v. 10, n. 7, e3810716247, 2021

(CC BY 4.0) | ISSN 2525-3409 | DOI: http://dx.doi.org/10.33448/rsd-v10i7.16247

Rodrigues, F. Á., Mcnally, D. J., Datnoff, L. E., Jones, J. B., Labbé, C., Benhamou, N., Menzies, J. G. \& Bélanger, R. R (2004). Silicon enhances the accumulation of diterpenoid phytoalexins in rice: a potential mechanism for blast resistance. Phytopathology, 9, 177- 183.

Rodrigues, F. D. A., Oliveira, L. D., Korndörfer, A. P. \& Korndörfer, G. H (2011). Silício: um elemento benéfico e importante para as plantas. Informações agronômicas 134, 14-20.

Sávio, F. L., Silva, G. C., Teixeira, I. R. \& Borém, A (2011). Produção de biomassa e conteúdo de silício em gramíneas forrageiras sob diferentes fontes de silicato. Semina: Ciências Agrárias, 32, 103-110.

Silva, G. B. P., Zanella, C. M., Delatorre, C. A., Chaves, M. S., Federizzi, L. C. \& Martinelli, J. A (2018). Organic acid carriers in tolerance to toxic aluminum in wheat. Soil Science, 48, 1-9.

Silva, M. R., Pereira, S. C., Rodrigues, F. A., Zanão Júnior, L. A., Fontes, R. L. \& Oliveira, M. G. A (2012). Silicon and manganese on the activity of enzymes involved in rice resistance against brown spot. Tropical plant pathology, 37, 339-345.

Sousa Junior, G. D. S. (2017). Silício atenua os efeitos tóxicos do alumínio em plantas jovens de cana-de-açúcar cultivadas em hidroponia. Dissertação de mestrado, pós-graduação em agronomia, universidade estadual paulista.

Taiz, L. \& Zeiger, E (2013). Fisiologia vegetal. (5a ed.), Artmed, 918 p.

Temiz, C. C., Téllez, L. I., Trejo, V. J., \& Merino, F. C. G (2017). Efecto de los elementos benéficos Al, Co, Se y Si en la nutrición de heliconias (Heliconia sp.). Agro Productividad, 10, 62-68.

Teodoro, P. E., Ribeiro, L. P., Oliveira, E. P., Corrêa, C. C. G. \& Torres, F. E (2015). Dry mass in soybean in response to application leaf with silicon under conditions of water deficit. Biosci. J., 31, 161-170.

Tokura, A. M., Neto, A. E. F., Curi, N., Carneiro, L. F. \& Alovisi, A. A (2007). Silício e fósforo em diferentes solos cultivados com arroz de sequeiro. Acta Sci. Agron., 29, 9-16.

Turakainen, M., Hartikainen, H. \& Seppanen, M (2005). Selenium in plants. In: EUROLA, M.; HIETAMNIEMI, V. Twenty years of selenium fertilization. Agrifood Research Reports. 108 p. 54-59.

Van Raij, B (2011). Fertilidade do Solo e Manejo de Nutrientes. Piracicaba: International Plant Nutrition Institute, p. 420.

Wang, L., Wang, Y., Chen, Q., Cao, W., Li, M. \& Zhang, F (2000). Silicon induced cadmium tolerance of rice seedlings. Journal of plant nutrition, 23, 13971406.

Wang, M., Gao, L., Dong, S., Sun, Y., Shen, Q. \& Guo, S (2017). Role of silicon on plant-pathogen interactions. Frontiers in Plant Science, 8, 701.

Yoshida, S (1965). Chemical aspects of the role of silicon in physiology of the rice plant. Bulletin of the National Institute of Agriculture Science, 15, 1-58. 